\title{
Contribution of benthic cysts to the population dynamics of Scrippsiella spp. (Dinophyceae) in Onagawa Bay, northeast Japan
}

\author{
Akira Ishikawa*, Akira Taniguchi \\ Laboratory of Biological Oceanography, Faculty of Agriculture, Tohoku University, Aoba-ku, Sendai, Miyagi 981, Japan
}

\begin{abstract}
In situ germination rate (cells $\mathrm{m}^{-2} \mathrm{~d}^{-1}$ ) and cyst deposition rate (cysts $\mathrm{m}^{-2} \mathrm{~d}^{-1}$ ) were monitored for Scrippsiella spp. dinoflagellates (mostly S. trochoidea) in Onagawa Bay on the northeastern Pacific coast of Japan, using a 'germinating cell trap/sampler' and sediment traps, respectively. Seasonal relationships of each rate to the abundance of vegetative cells in the water column were investigated. Germination of the cysts on the surface sediment occurred throughout the year, but the germination rate varied seasonally and was strongly correlated with temperatures of the bottom water and the sediment, indicating that temperature is a principal factor controlling germination. Blooms occurred prior to the increase in germination rate in July, indicating that bloom initıation is not necessarily a direct consequence of mass cyst germination. Seasonal changes in recruitment ratio (ratio of the germination rate to standing crops of the vegetative cell population in the water column) revealed that, compared to summer, a large part of the winter population of vegetative cells was contributed by cyst germination but increased germination during periods of warmer temperatures contributed little to the bloom population - on the contrary, spring and summer populations appeared to be largely derived from vegetative growth. Sexual reproduction and encystment of Scrippsiella spp. in natural populations seemed to be enhanced by serial, short-term depletion of nutrients during summer. Large encystment events appeared to result in bloom termination. These findings elucidate the population dynamics of Scrippsiella spp. in Onagawa Bay. An annual budget of seed population was also calculated.
\end{abstract}

KEY WORDS: Scrippsiella spp. Cyst - Germination rate Cyst deposition rate $\cdot$ Seed population

\section{INTRODUCTION}

Many dinoflagellates living in marine and freshwater environments have been recorded as producing resting cysts during their life histories. The significant function or role of such cysts has been emphasized by many studies (e.g. Wall 1971, 1975, Anderson \& Wall 1978, Dale 1983, Anderson 1984). The concept that the cysts act as 'seed populations' or 'seed beds' in their population dynamics (Prakash 1967, Wall 1971, Steidinger 1975) is now widely accepted.

Important processes in the dynamics of the seed population are additions due to deposition of new cysts

\footnotetext{
- Present address: Faculty of Bioresources, Mie University, Kamihama, Tsu, Mie 514, Japan

E-mail: ishikawa@bı.mie-u.ac.jp
}

formed in the upper water column, advection of old cysts by mixing of sediment, and losses due to the mixing of sediment and to degradation, predation, senescence and cyst germination. Originally, this hypothesis was summarized by De Statio (1989) for animal egg banks. The magnitude of each process can vary both spatially and temporally. Among these processes, addition and loss due to mixing and movement of sediment do not significantly alter the population of cysts. The processes that are directly responsible for seasonal changes of the cyst population, and therefore the vegetative population, are loss due to germination and addition due to deposition. Germination is thought to be responsible for the initiation of blooms (e.g. Dale 1983) and bloom termination a direct result of cyst deposition (Anderson 1984). Therefore, direct measurements in situ of these 2 processes are indispens- 


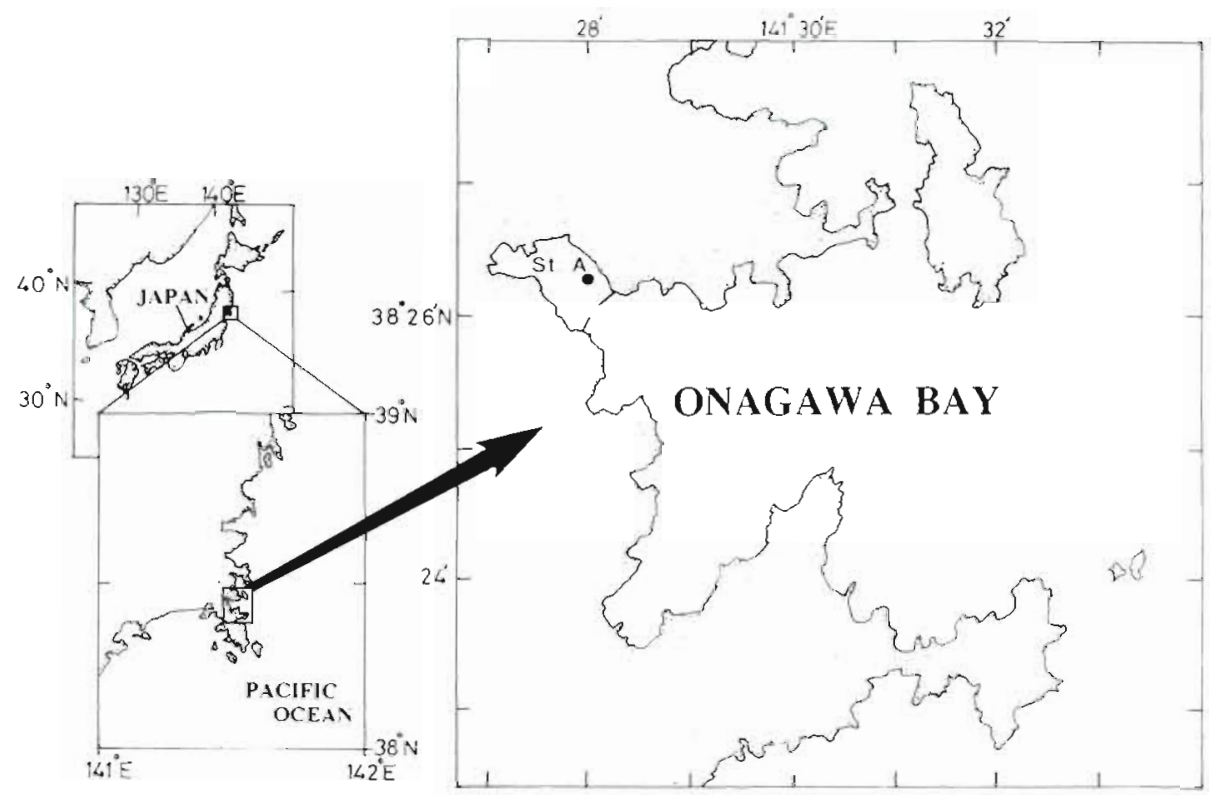

Fig. 1 Location of the sampling station in Onagawa Bay, Japan

able in studies on population dynamics of cyst-forming dinoflagellates

The photosynthetic dinoflagellate Scrippsiella trochoidea (Stein) Loeblich III is the most dominant species among cyst-forming dinoflagellates in Onagawa Bay in northeast Japan (Ishikawa 1992). The physiology and biochemistry of various life history stages of this species, including cysts in a laboratory setting, are well documented (Wall et al. 1970, Watanabe et al 1982, Binder \& Anderson 1986, 1987, 1990, Lirdwitayaprasit et al. 1990, Meksumpun et al. 1994, Uchida 1994). In contrast, information about the ecology of Scrippsiella in nature is lacking. Ishikawa \& Taniguchi (1994) have speculated seasonal behavior of Scrippsiella spp. (mostly $S$ trochoidea) in Onagawa Bay on the basis of both incubation experiments involving cysts collected from the bottom sediments and field observations of vegetative cells in the water column.

We have recently developed and used a sampling device, the 'germinating cell trap/sampler', to collect germinating cells of dinoflagellate cysts in surface sediments (Ishikawa et al. 1995) in order to monitor germination of Scrippsiella trochoidea cysts in situ from the bottom sediment in Onagawa Bay. In addition, we also monitored cyst deposition in the bay using sediment traps. The results obtained are discussed in this paper with regard to: (1) factors controlling germination of the cysts, (2) seasonsal relationships between the germination pattern of the cysts in situ and the vegetative population in the water column, and (3) the seasonal relationship between the deposition of newly formed cysts from the water column and the vegetative population in the water column. The data presented elucidate the population dynamics of $S$. trochoidea and allow us to construct an annual budget of the cyst population in sediments in Onagawa Bay.

\section{MATERIALS AND METHODS}

Since not all Scrippsiella cysts occurring in Onagawa Bay are S. trochoidea (Ishikawa \& Taniguchi 1993), the vegetative cells in the water column should be considered Scrippsiella spp. However, other species of Scrippsiella constitute only a fraction of the Scrippsiella cysts in the sediment, and therefore the collective name Scrippsiella spp. is almost synonymous with S. trochoidea (cf. Ishikawa \& Taniguchi 1994).

Water sampling. Sampling was conducted at Stn A $\left(38^{\circ} 26.27^{\prime} \mathrm{N}, 141^{\circ} 28.00^{\prime} \mathrm{E}\right)$ in the innermost part of Onagawa Bay (Fig. 1). While a few small streams pour into the area, nutrient-rich waste water from several sea food factories on the shore of the bay has led to significant eutrophication in the bay. The average water depth at Stn A was $17 \mathrm{~m}$ and the bottom sediment was fine mud. All sampling was done before noon 108:00 to 12:00 h)

Water samples were collected with a Van-Dorn sampler at depths of 0,5 and $10 \mathrm{~m}$ and at $0.5 \mathrm{~m}$ above the bottom, 3 to 7 times a month from October 1992 to January 1994 and once a month from February to April 1994. Nutrient concentrations and vegetative cell counts of Scrippsiella spp. were determined at each depth. Samples for nutrient analyses $\left(\mathrm{NO}_{3}, \mathrm{NO}_{2}, \mathrm{NH}_{4}\right.$ and $\mathrm{PO}_{4}$ ) were filtered through a Whatman GF/F glassfiber filter and the filtrates were frozen until later analysis on a TRAACS $800^{\mathrm{TM}}$ autoanalyzer (Bran Luebbe Co., Ltd). Samples for cell counts were fixed by 
adding borax buffered formaldehyde at a final concentration of $2 \%$. Depending on the density of cells, a 50 to $100 \mathrm{ml}$ aliquot of these samples was settled in a Utermöhl chamber for at least $12 \mathrm{~h}$ and the cells counted under an Olympus IMT-2 inverted microscope at $200 \times$ magnification. The cell densities were plotted against their respective depths and the area enclosed by this vertical distribution line was then integrated to obtain an estimate of the integrated vegetative population (cells $\mathrm{m}^{-2}$ ).

Water and sediment temperature. Vertical profiles of temperature at Stn A were recorded by a DBT (Digital Bathythermograph) during the period from October 1992 to April 1994. The temperature of the sediment was measured at $\mathrm{ca} 1 \mathrm{~cm}$ depth, once a month, by the same method described in Ishikawa \& Taniguchi (1994).

Germination in situ. Sampling of germinating cells in situ was carried out monthly at Stn A from February 1993 to January 1994 using the 'germinating cell trap/sampler' (Ishikawa et al. 1995). The trap/sampler consists of an inverted vessel of 36 l capacity which covers a known area of the sea bottom $\left(0.09 \mathrm{~m}^{2}\right)$ and a magnet pump with an intake hose which samples the water and plankton entrapped in the vessel. The sides of the vessel are covered with a fine mesh to remove plankton from the water sucked into the vessel by pumping. It was deployed from a surface platform and allowed to settle on the sea bottom. Germinated and entrapped plankton were pumped up at a constant rate of $181 \mathrm{~min}^{-1}$ for 7 min daily on 5 consecutive days. The plankton were collected with a hand net of $10 \mu \mathrm{m}$ mesh size. The collected sample (ca $500 \mathrm{ml}$ ) was transferred into a sample bottle and fixed with borax buffered formaldehyde at a final concentration of $2 \%$. The samples were then kept at $5^{\circ} \mathrm{C}$ in the dark until analysis

A $1 / 20$ to $1 / 4$ aliquot was taken from each of 5 samples and settled in a Utermöhl chamber for at least $12 \mathrm{~h}$ before counting. Vegetative cells were then counted under an epifluorescence inverted microscope (Olympus IMT-2 + REF) at $200 \times$ magnification. The counts for every $i$ th sample were converted into the cell number sampled by a 7 min pumping on $i$ th day $\left(C_{1}\right)$ and then total cell number entrapped by the trap/sampler on ith day $\left(N_{1}\right)$ was calculated by the following equation.

$$
N_{l}=C_{i} /\left(1-R t_{i}\right)
$$

where $R t$, is cell density in the trap/sampler just after pumping relative to that just before pumping, which could be obtained by the theoretical equation (Eq. 2) in Ishikawa et al. (1995), i.e. $e^{-3.500}=0.03$ in this case. The product of $N_{i}$ and $R t_{i}$ is the residual cell number carried over to the next pumping. Then, the number of the newly germinated cells from the bottom be- tween the $(i-1)$ th and $i$ th days $\left(G_{1-1}\right)$ was calculated by subtracting the cell number carried over $\left(N_{i-1} \times\right.$ 0.03 ) from $N_{n}$ i.e.

$$
G_{i-1}=N_{i}-N_{i-1} \times 0.03
$$

Finally $G_{t-1}$ was converted into daily germination rate (cells $\mathrm{m}^{-2} \mathrm{~d}^{-1}$ ). The mean of the germination rates obtained for 5 days is given below as monthly average germination rate.

Sinking cysts. Sinking cysts were collected with 2 cylindrical sediment traps moored at 2 and $10 \mathrm{~m}$ above the bottom at $S \operatorname{tn} A$. The sediment traps were $53 \mathrm{~cm}$ in height and $14.5 \mathrm{~cm}$ in inner diameter, making a collecting area of $165 \mathrm{~cm}^{2}$. The basic configuration of the traps is given by Sasaki \& Nishizawa (1981). The sampling chamber on the bottom of the trap was split into 6 equal compartments. The collection at $2 \mathrm{~m}$ above the bottom was made during the period from October 1992 to April 1994, and that at $10 \mathrm{~m}$ above the bottom from April 1993 to April 1994. The traps were filled with $3.4 \% \mathrm{NaCl}$ solution just before deployment without addition of preservatives. The traps were deployed for 4 days per month during the first half of this study period, i.e. from October 1992 to the beginning of August 1993. Throughout the latter half of the study period the traps were moored continuously and sampling chambers were emptied successively at intervals from several days to 1 month.

A $1 / 2$ to $1 / 12$ aliquot of the sample was sonicated and sieved through a $100 \mu \mathrm{m}$ mesh screen onto a $20 \mu \mathrm{m}$ mesh screen. The sieved fraction (20 to $100 \mu \mathrm{m}$ ) was suspended in $20 \mathrm{ml}$ of filtered sea water containing borax buffered formaldehyde at $2 \%$. From this suspension, a 0.25 to $0.5 \mathrm{ml}$ aliquot was spread over a slide glass and intact cysts of Scrippsiella spp. counted under an Olympus BH-2 microscope at 100× magnification. Counts were carried out in triplicate for each sample to calculate the number of cysts deposited per day (cysts $\mathrm{m}^{-2} \mathrm{~d}^{-1}$ ).

Data analysis. The recruitment ratio $\left(\mathrm{d}^{-1}\right)$ was calculated as follows: the germination rate (cells $\mathrm{m}^{-2} \mathrm{~d}^{-1}$ ) was divided by the standing crop of vegetative cells in the water column (cells $\mathrm{m}^{-2}$ ). The standing crops (the total integrated cell number throughout the entire water column) were expressed as a mean value for the corresponding days of the in situ germinating cell collections. Annual germination from the bottom was calculated by linear integration of the monthly average germination rates obtained throughout the period from February 1993 to January 1994 The annual cyst deposition at $2 \mathrm{~m}$ above the bottom was obtained by summing a linearly integrated value of monthly depositions from February to August 1993 and that of the daily depositions from August 1993 to January 1994. 


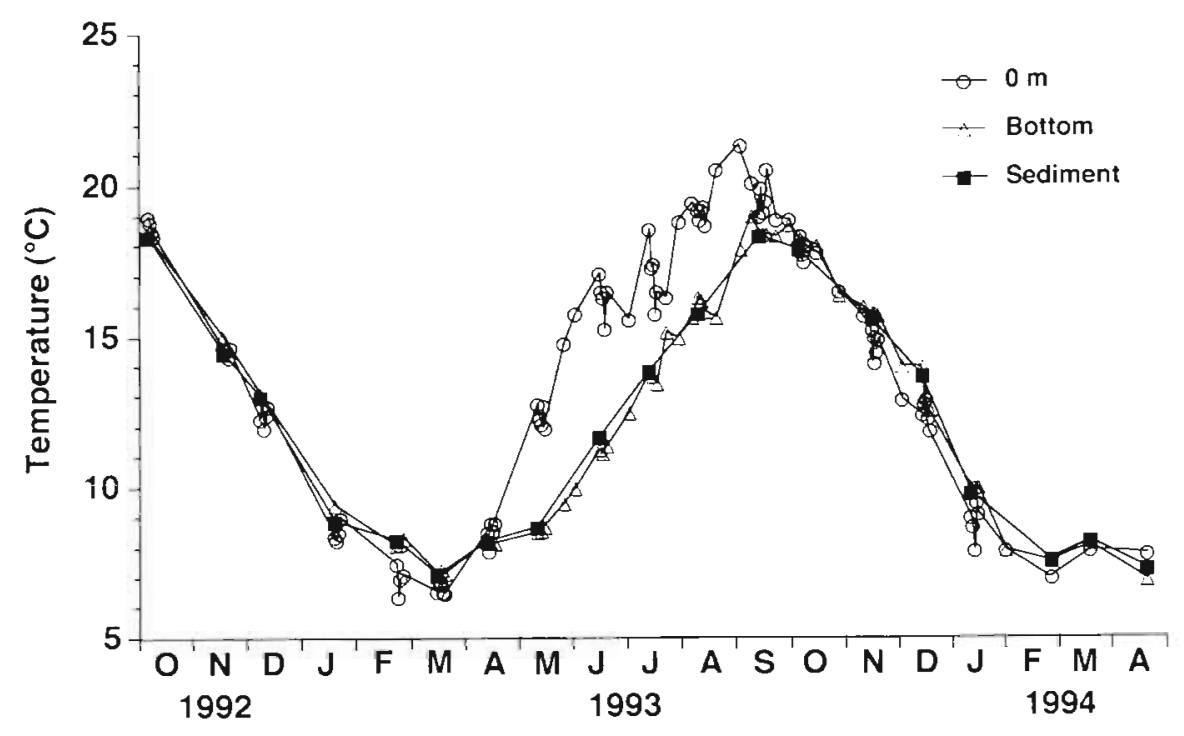

Fig. 2. Seasonal changes of temperature at different depths in the water column and at ca $1 \mathrm{~cm}$ depth in the sediment at $\operatorname{Stn} A$ in Onagawa Bay. Bottom here means $0.5 \mathrm{~m}$ above the bottom

\section{RESULTS}

\section{Environmental conditions}

Thermal stratification at Stn A was evident from May to September but not from October to April (Fig. 2). Temperature in the water column was lower than $10^{\circ} \mathrm{C}$ from January to April in both 1993 and 1994. Temperature at $0 \mathrm{~m}$ (the surface) reached $10^{\circ} \mathrm{C}$ in April/May 1993 and further increased to the seasonal maximum of $21.3^{\circ} \mathrm{C}$ by the beginning of September 1993. Seasonal changes in temperature of the sediment and at $0.5 \mathrm{~m}$ above the bottom showed a similar trend, with temperature values lower than $10^{\circ} \mathrm{C}$ from January to May 1993 and increasing to the seasonal maxima of 18.3 and $19.0^{\circ} \mathrm{C}$, respectively, by early September 1993 . The seasonal minima of the sediment temperature in March 1993 and the surface water temperature in February 1993 were 7.1 and $6.4^{\circ} \mathrm{C}$, respectively.

Concentrations of total nitrogenous nutrients $\left(\mathrm{NO}_{3}+\right.$ $\left.\mathrm{NO}_{2}+\mathrm{NH}_{4}\right)$ and phosphate $\left(\mathrm{PO}_{4}\right)$ at $\mathrm{Stn} \mathrm{A}$ changed seasonally in a similar fashion, being generally high in cold seasons (October to February/March) and low in warm seasons (March/April to September) (Fig. 3A, B). The lowest values observed in warm seasons in the upper 2 layers ( 0 and $5 \mathrm{~m}$ depth) were $0.3 \mu \mathrm{M}$ for nitrogen and $0.0 \mu \mathrm{M}$ for phosphate, while several spikes emerged. The concentrations in the 2 deeper layers ( $10 \mathrm{~m}$ below the surface and $0.5 \mathrm{~m}$ above the bottom) were relatively high, varying from 0.4 to $12.3 \mu \mathrm{M}$ for nitrogen and 0.1 to $1.3 \mu \mathrm{M}$ for phosphate. Generally, nutrients were sometimes depleted in the upper layers during the warm seasons but never in the $10 \mathrm{~m}$ and bottom layers

\section{Seasonal change in abundance of vegetative cells}

Vegetative cells of Scrippsiella spp, always occurred at Stn A during the study period except on a few occasions in November and December 1992 (Fig. 4). In 1993, the total integrated cell number in the water column (from the surface down to $0.5 \mathrm{~m}$ above the bottom) increased markedly from $1.4-3.2 \times 10^{6}$ cells $\mathrm{m}^{-2}$ in April/May to the summer maximum of $3.9 \times 10^{8}$ cells $\mathrm{m}^{-2}$ in mid-July 1993 . The abundance was generally around $10^{7}$ to $10^{8}$ cells $\mathrm{m}^{-2}$ until early October 1993 and then decreased sharply to around $10^{5}$ cells $\mathrm{m}^{-2}$ by late October. The abundance was low in the winters of $1992 / 1993$ and $1993 / 1994$, around $10^{5}$ to $10^{6}$ cells $\mathrm{m}^{-2}$

\section{Seasonal change of germination in situ}

Germination of Scrippsiella spp. from the bottom sediment occurred throughout the year, but the germination rate varied seasonally (Fig. 5). The rate was low, from 444 to 942 cells $\mathrm{m}^{-2} \mathrm{~d}^{-1}$ during the period from February to June 1993, increasing from July to October up to the seasonal maximum of 7758 cells $\mathrm{m}^{-2} \mathrm{~d}^{-1}$, with a slight decrease in August. It decreased rapidly in November and remained relatively low until January 1994.

The recruitment ratio was always very low; even at the maximum in December 1993 the ratio was $2.19 x$ $10^{-3} \mathrm{~d}^{-1}$ (Fig. 6). The seasonal trend of the recruitment ratio was generally opposite to that of the vegetative cells, being low when vegetative cells were abundant and vice versa. 


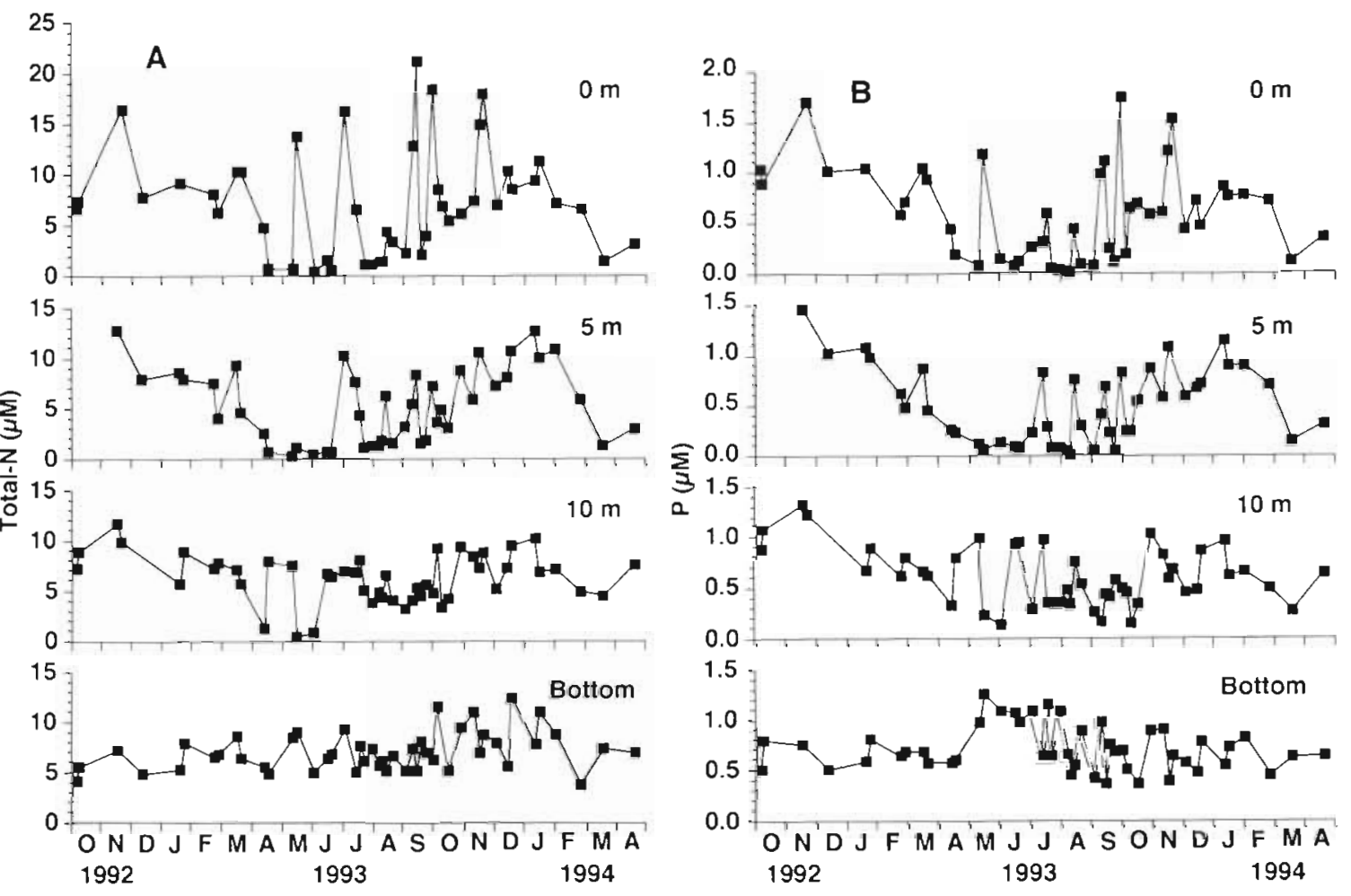

Fig. 3. Seasonal changes in concentrations of $(\mathrm{A})$ total nitrogenous nutrients $\left(\mathrm{NO}_{3}, \mathrm{NO}_{2}, \mathrm{NH}_{4}\right)$ and $(\mathrm{B})$ phosphate $\left(\mathrm{PO}_{4}\right)$ at different depths in the water column at $S$ tn $A$ in Onagawa Bay. Bottom here means $0.5 \mathrm{~m}$ above the bottom

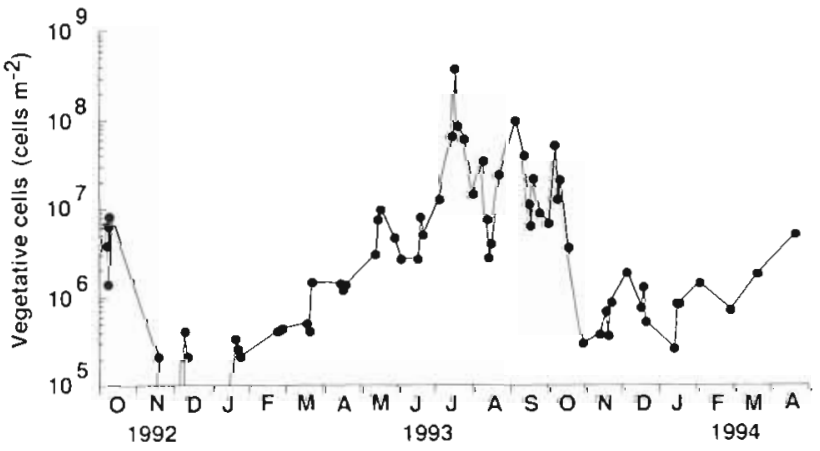

Fig. 4 Scrippsiella spp. Seasonal change in integrated number of vegetative cells throughout the water column (from the surface to $0.5 \mathrm{~m}$ above the bottom) at $\mathrm{Stn} \mathrm{A}_{\mathrm{i}}$ in Onagawa Bay

\section{Seasonal changes in cyst deposition rate}

The seasonal trend in deposition rate of Scrippsiella spp. cysts was similar at 2 and $10 \mathrm{~m}$ above the bottom (Fig. 7). Though cyst deposition occurred almost constantly throughout the study period, the deposited cysts were especially abundant at both depths from the beginning of September to the middle of October 1993, when 2 peaks in the deposition rate were distinguished. The first peak was observed in the first half of September with the annual maxima of $3.16 \times 10^{5}$

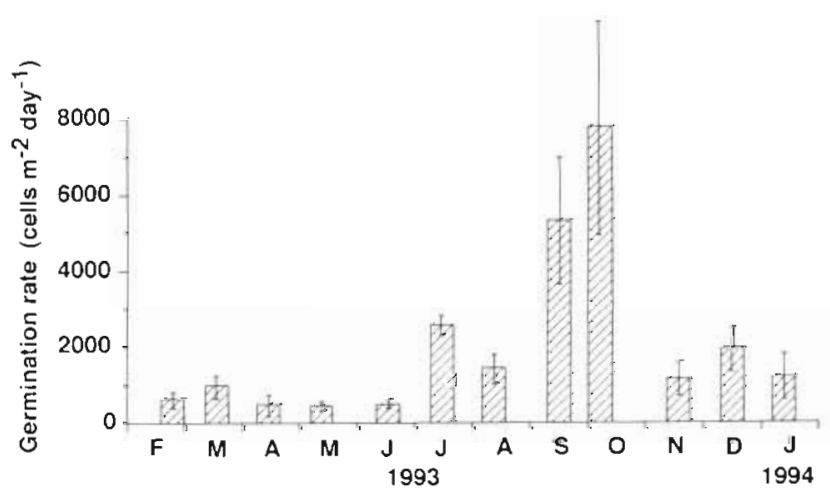

Fig. 5. Scrippsiella spp. Seasonal change in germination rate of cysts from the surface sediment at $\operatorname{Stn} A$ in Onagawa Bay. Bars represent \pm SD

and $3.14 \times 10^{5}$ cysts $\mathrm{m}^{-2} \mathrm{~d}^{-1}$ at 2 and $10 \mathrm{~m}$ above the bottom, respectively. The second peak accurred from the end of September to the middle of October with secondary maxima of $8.29 \times 10^{4}$ and $1.19 \times 10^{5}$ cysts $\mathrm{m}^{-2} \mathrm{~d}^{-1}$ at the 2 respective depths. In other seasons, deposition rates were generally on the order of $10^{3}$ cysts $\mathrm{m}^{-2} \mathrm{~d}^{-1}$ at both depths. The deposition rate at $2 \mathrm{~m}$ above the bottom in the period from December 1992 to June 1993 was the lowest, with a value below $0.35 \times 10^{4}$ cysts $\mathrm{m}^{-2} \mathrm{~d}^{-1}$. Most of the cysts deposited were $S$. trochoidea. 


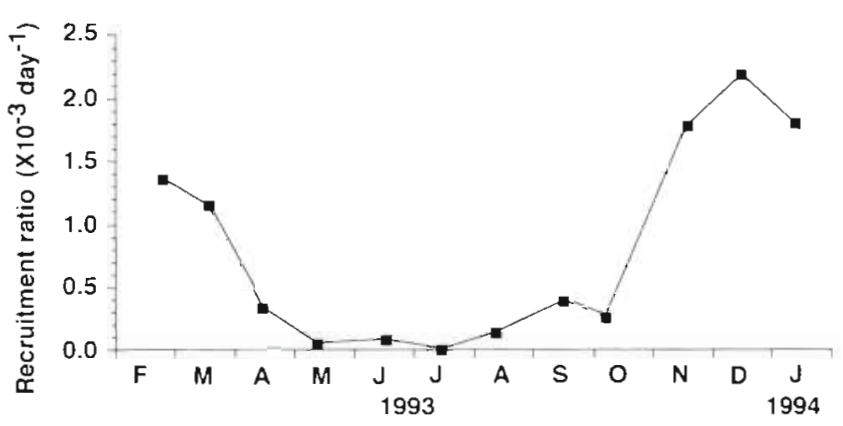

Fig. 6. Scrippsiella spp. Seasonal change in recruitment ratio (germination rate/standing crops of the vegetative cell population in the water column) at Stn A in Onagawa Bay

\section{Seed population budget}

Annual germination from the botlom and cyst deposition at $2 \mathrm{~m}$ above the bottom were $0.73 \times 10^{6}$ cells $\mathrm{m}^{-2} \mathrm{yr}^{-1}$ and $6.49 \times 10^{6}$ cysts $\mathrm{m}^{-2} \mathrm{yr}^{-1}$, respectively. This result indicates that about 9 times more cysts were deposited than germinated on an annual basis at $\operatorname{Stn} \mathrm{A}$.

\section{DISCUSSION}

\section{Factors controlling cyst germination}

Temperature has previously been indicated as the primary environmental factor controlling germination of dinoflagellate cysts (Dale 1983, Pfiester \& Anderson 1987). Cysts of Scrippsiella spp. collected from Onagawa Bay can germinate at temperatures between 5 and $25^{\circ} \mathrm{C}$, which completely covers the annual temperature range $\left(5\right.$ to $\left.21^{\circ} \mathrm{C}\right)$ in the sediment and bottom layer of the water column in the bay (Ishikawa 1995). The optimal range for germination is around 1.5 to $20^{\circ} \mathrm{C}$ and germination rates at $5^{\circ} \mathrm{C}$ are very low (Ishikawa 1995). Germination rates in situ (Fig. 5) changed seasonally in parallel with the temperature of the bottom water and sediment (Fig. 2), showing a response to temperature similar to that observed experimentally. Abundance of living cysts in the top $1 \mathrm{~cm}$ of the sediment at $\mathrm{Stn} A$ was almost constant, being on the order of $10^{2}$ cysts $\mathrm{cm}^{-3}$ during the study period (Ishikawa 1995). Therefore the seasonal trend in germination rate is probably unaffected by cyst abundance in the sediments. Temperature is therefore the dominant factor controlling in situ germination of Scrippsiella spp. cysts. On the other hand, there were a few disagreements in seasonal trend between temperature (Fig. 2) and germination rate (Fig. 5). For example, although the sediment temperature exceeded $10^{\circ} \mathrm{C}$ in June, the germination rate did not increase. The rate decreased in August when the sediment temperature was within the optimal range $\left(15.8^{\circ} \mathrm{C}\right)$. Furthermore, despite the sediment temperature still exceeding $15^{\circ} \mathrm{C}$, the rate decreased dramatically in November. Ishikawa \& Taniguchi (1994) suggest that the in situ germination of Scrippsielld spp. cysts in Onagawa Bay may be regulated by lowered saturation of dissolved oxygen (DO) during thermally stratified periods. This could explain the decreases in germination observed during

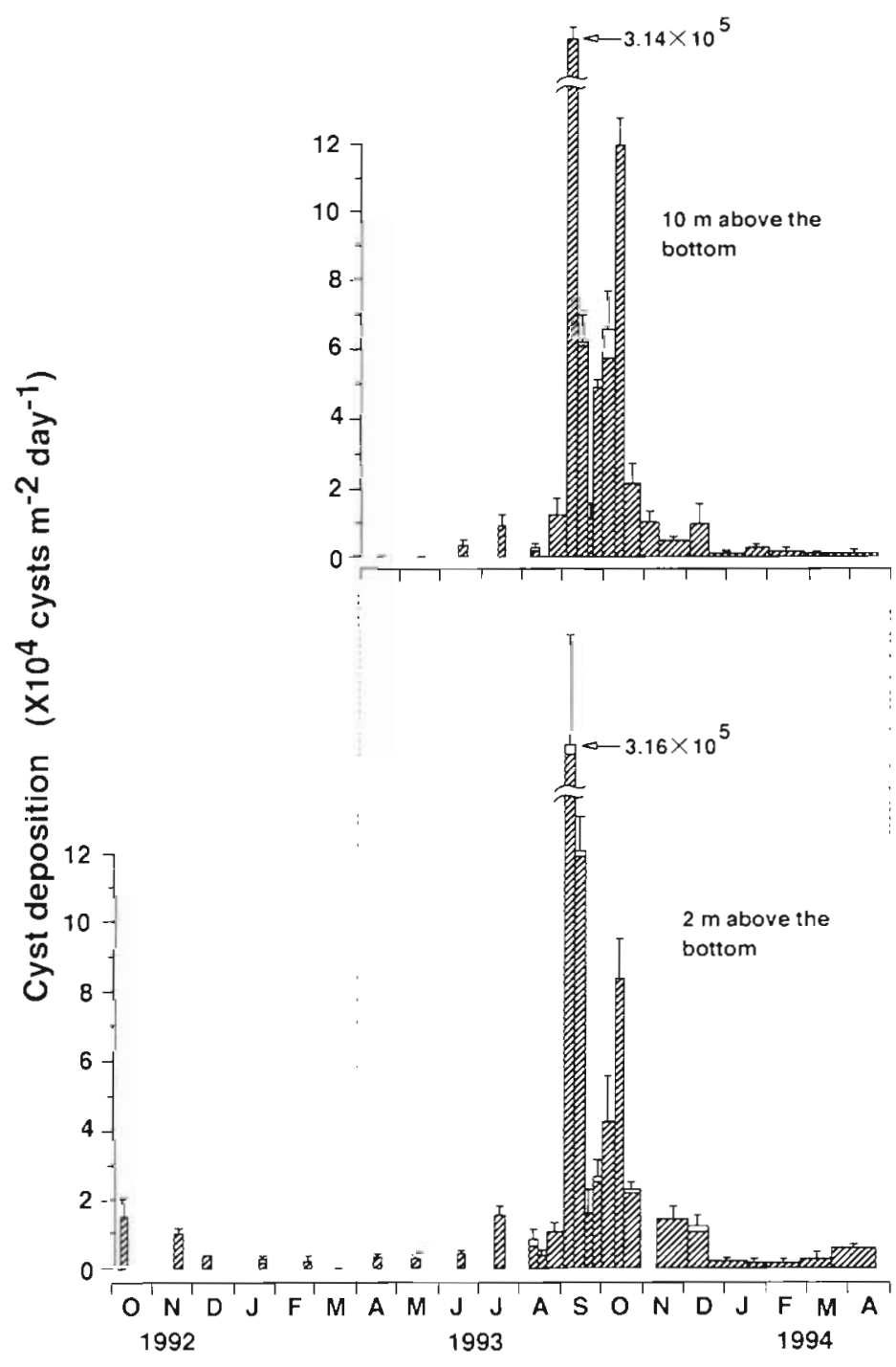

Fig. 7. Scrippsiella spp. Seasonal changes in cyst deposition monitored by sediment traps at 2 and $10 \mathrm{~m}$ above the bottom at Stn $\mathrm{A}$ in Onagawa Bay. Shaded and open columns represent cysts of $S$. trochoidea and other Scrippsiella species, respectively. Bars represent +SD 
stratified seasons (June and August). However, the marked decrease in November cannot be explained by low DO, since the water column was vertically mixed, as indicated by a homogeneous temperature distribution. Nor can it be explained by immaturity of cysts, since most cysts were formed before the first half of October (Fig. 7) and had already exceeded the mandatory dormancy period of ca 4 wk (Binder \& Anderson 1987). It is possible that Scrippsiella spp. possesses an endogenous annual germination rhythm, as reported for cysts of Alexandrium tamarense (Anderson \& Keafer 1987) and Chattonella spp. (Imai et al. 1989, Imai 1990), which may depress the in situ germination rate of $S$. trochoidea cysts in late autumn (November-December).

\section{Germination in situ and vegetative population}

Vegetative cells of Scrippsiella spp. sampled at Stn A might include those transported from other localities in the bay. However, Stn $A$ is located in the inner harbor where effects of advection and exchange of water are small. Additionally, it has been found that the diatom flora in the harbor is independent from that outside (Inouye pers. comm.), indicating that the populations at $\operatorname{Stn} \mathrm{A}$ are largely native to the harbor water. De Statio $(1989,1990)$ has shown for certain cladoceran and copepod species in a freshwater pond that the timing and magnitude of emergence from the sediment differ significantly with depth. However, considering that the germination of Scrippsiella spp. cysts in the bottom sediment appears to be controlled mainly by temperature, and the seasonal trend in sediment temperature is almost identical at all stations scattered over the bay (Ishikawa 1995), it can be assumed that the seasonal pattern of germination is similar throughout the bay. It is, therefore, reasonable to assume that spatial variation in germination is small.

It is interesting that the germination rate remained low in April and May (Fig 5) when blooms of Scrippsiella spp. began in the upper water column (Fig 4) Temporal discrepancies were also observed between the seasonal maximum of the vegetative population (July) and the seasonal peak of germination (October). The seasonal trends in the recruitment ratio (Fig 6) and abundance of vegetative cells (Fig. 4) were generally opposite, indicating that cysts do not contribute significantly to the bloom magnitude, but that blooms are formed largely as a result of vegetative growth. In contrast, the higher recruitment ratio in winter months indicates that a comparatively large part of the winter population of vegetative cells originates from cyst germination during winter (Fig. 6). However, the magnitude of the winter population cannot be explained only by recruitment of germinated cells, since the recruitment ratio even at the maximum in winter was very low, $2.19 \times 10^{-3} \mathrm{~d}^{-1}$. Previous laboratory experiments have demonstrated that vegetative cells of $S$. trochoidea cannot grow at $5^{\circ} \mathrm{C}$ but some of the cells survive over $30 \mathrm{~d}$, and positive growth of the cells occurs from over $10^{\circ} \mathrm{C}$ up to at least $25^{\circ} \mathrm{C}$ (Ishikawa 1995). Considering that the minimum temperature in winter was above $6^{\circ} \mathrm{C}$ (Fig. 2), a part of the vegetative population must survive from the previous blooms and may grow slowly during the winter season, contributing to the winter population

It has been suggested that cysts play an important role in bloom initiation (Wall 1971, 1975, Anderson \& Wall 1978, Dale 1983, Anderson 1984). The evidence obtained in this study, however, demonstrates that high germination rates or synchronized mass germination of the cysts from the surface sediment is not necessary for Scrippsiella spp. bloom initiation. The presence of vegetative cells in the water column is important at the time when environmental conditions become suitable for vegetative growth; the magnitude of the subsequent bloom is dependent on vegetative growth rather than recruitment of newly germinated cells. This growth, in turn, is controlled by complex factors such as water temperature, light intensity, concentration of nutrients, competition with other phytoplankters, and grazing by zooplankton. For example, development of the vegetative population in the first half of 1993 (Fig. 4) occurred as surface temperature increased up to its seasonal maximum around $20^{\circ} \mathrm{C}$ (Fig. 2), the optimal growth temperature observed in the laboratory (Ishikawa 1995). Furthermore, the large nutrient fluctuations at 0 and $5 \mathrm{~m}$ depth during warm seasons (Fig. 3A, B) might have generated the wider fluctuations of the vegetative population shown in Fig. 4.

Although it has generally been said that cysts are important for surviving unfavorable conditions for vegetative growth, cyst-formation itself is not necessarily advantageous for proliferation in coastal waters after environmental conditions improve. However, incessant germination, even in unfavorable conditions, as well as the broad temperature range for vegetative growth of Scrippsiella spp., is highly advantageous for building the large population, allowing it to dominate over other populations in northern temperate coastal waters such as Onagawa Bay, where environmental conditions vary widely throughout the year. Such incessant germination enables the vegetative cells to immediately exploit the favorable growth conditions. This is the most likely reason why $S$. trochoidea is the most dominant dinoflagellate in Onagawa Bay and why it dominates the world's coastal oceans (cf. Wall et al. 1970). 


\section{Cyst deposition and the vegetative population}

It is generally known that sediment traps measure sinking flux at different efficiencies according to their configuration (e.g. Gardner 1980a, b). Furthermore, the admixture of materials resuspended from the surface sediment makes the interpretation of sedimentation processes complicated (Matsuoka et al. 1989). The use of sediment trap data for quantitative analysis has serious problems in shallow sea areas. However, sediment traps are useful for qualitative analysis, such as the timing and species composition of newly formed cyst populations, or for relative measures of the magnitude of cyst formations between species (Matsuoka et al. 1989). The following discussion of data obtained at Stn $A$ is to be understood largely in a relative sense

As reported for many cyst-forming dinoflagellates (Dale 1983, Pfiester \& Anderson 1987, Hori 1993), the cysts of Scrippsiella trochoidea are formed through sexual processes (Watanabe et al. 1982, Watanabe 1993). Many factors such as temperature, day length, irradiance and nutrient depletion have been studied as possible triggers associated with sexuality and the resultant encystment in dinoflagellates (cf. Pfiester \& Anderson 1987). Among these factors, nutrient depletion, especially nitrogen and/or phosphorus deficiency, has been indicated to be the primary trigger for encystment (e.g. von Stosch 1973, Pfiester 1977, Anderson et al. 1984, 1985, Sako et al. 1987. Chapman \& Pfiester 1995). Watanabe et al. (1982) observed that the encystment of $S$. trochoidea was enhanced by nutrient limitation, either of nitrogen or phosphate, but found that it also occurred in nutrient-rich control cultures. Furthermore, light and temperature optima for the encystment were the same as those for maximum vegetative growth. In this study, nutrient concentrations in the upper layer ( 0 to $5 \mathrm{~m}$ ) were observed to fluctuate widely in summer, but complete depletion rarely occurred (Fig. 3A, B), probably due to high nutrient input to the innermost part of the bay from food factories on the shore. Rapid decreases in nutrient concentrations as well as extended periods of low $\mathrm{N}$ and $\mathrm{P}$ concentration in the upper layers during the summer may have gradually depleted cellular nutrient reserves and enhanced sexual reproduction. As a result of this nutrient depletion large cyst deposition events might have been recorded from September to October 1993 when temperature was in the optimal range for growth (Fig. 7)

The termination of the Scrippsiella spp. bloom in Onagawa Bay (Fig. 4) was also recorded when temperature was still in the optimal range for the vegetative growth. Anderson et al. (1983) suggested that a major factor in the decline of Alexandrium tamarense blooms is the switch from asexual to sexual reproduction to form planozygotes, so the mass encystments mentioned above (Fig 7) could have resulted in the bloom termination after early October 1993. The same tendency has also been reported for $A$. catenella by Takeuchi (1992). Therefore, it appears that the Scrippsiella spp populations may undergo depletion of cellular nutrient reserves due to rapid vegetative growth in summer, so that by the end of this season the cells become susceptible even to short-term drops in nutrient concentration. Sexual reproduction is enhanced and mass encystment terminates the bloom during the optimal temperature period for growth. This life history strategy favors the deposition of large numbers of cysts into the sediment as seeds for successive years (cf. Nakahara \& Sako 1987).

\section{Annual budget of the seed population in Onagawa Bay}

On an annual basis, the magnitude of deposition was much larger than that of germination, suggesting that the cysts will never be depleted in the sediment if vegetative cells continue producing cysts every year. The abundance of living cysts in the top $1 \mathrm{~cm}$ of the sediment in. February 1993, when observations of in situ germination rate were begun, was almost $6.9 \times 10^{6}$ cysts $\mathrm{m}^{-2}$ (Ishikawa 1995). On the other hand, total annual germination from February 1993 to January 1994 was estimated as $0.73 \times 10^{6}$ cells m ${ }^{-2} \mathrm{yr}^{-1}$. Assuming that losses from the seed population by degradation, predation, senescence, advection and vertical replacement of sediment are negligible, the initial stock was numerically equivalent to 9.5 times the annual germination; in other words, cysts representing $9.5 \mathrm{yr}$ germination were stocked in the top $1 \mathrm{~cm}$. The cysts are also distributed abundantly below $1 \mathrm{~cm}$ depth and remain viable (Ishikawa 1992, 1995). If vertical mixing of the sediment frequently extends to more than $1 \mathrm{~cm}$, the size of the stock is considerably larger This is direct evidence of the existence of a 'seed population' as suggested by Prakash (1967), Wall (1971) and Steidinger (1975). Such a seed population allows the species to survive through periods of unpredictable conditions imposed upon the vegetative population by predation by zooplankton and nutrient depletion.

\section{CONCLUSIONS}

The annual population dynamics of Scrippsiella spp. in Onagawa Bay appear to be controlled by seasonal variations of temperature in the surface layer and at the bottom. The vegetative population in winter is supported not only by cells which have survived from the previous summer but also by germination in winter, 
although the germination rate is low due to low temperatures $\left(6\right.$ to $\left.10^{\circ} \mathrm{C}\right)$. The bloom is probably initiated by these vegetative cells in April/May as surface temperature increases to near $10^{\circ} \mathrm{C}$. It must be noted that this bloom occurs prior to the increase in germination rate in July. Both existing vegetative cells and newly germinated vegetative cells contribute to bloom initiation, which reaches the seasonal maximum during the period from July to September, when the surface temperature is optimal for vegetative growth.

Although sexual reproduction and subsequent encystment occur in the vegetative population throughout the year, encystment is most active in the period from September to October. This mass encystment is likely enhanced by short-term depletion of nutrients during the summer period. The rate of germination from the surface sediment also attains a maximum in October. Nevertheless, germination is insufficient to replenish the loss of vegetative cells. On an annual basis, the number of germinated cells from sediment, $0.73 \times 10^{6}$ cells $\mathrm{m}^{-2} \mathrm{yr}^{-1}$, is 9 times lower than the number of deposited cysts, $6.49 \times 10^{6}$ cysts $\mathrm{m}^{-2} \mathrm{yr}^{-1}$ i an excess deposit of cysts into the seed population is evident.

Acknowledgements. We are grateful to Mr Y Kotani of the Tohoku National Fisheries Research Institute and Mr T Fujiwara of the Miyagi Prefectural Fisheries Research and Development Center for their kind help in nutrient analysis. We also thank anonymous reviewers for their constructive comments on the manuscript. The collaboration of Mr K. Abe and other staff members of the Marine Fisheries Laboratory of Tohoku University, and of our colleagues at the university, in field work is greatly appreciated. This work was partially supported by research grant nos. 06839003 and 07836002 from the Japan Ministry of Education, Science and Culture

\section{LITERATURE CITED}

Anderson DM (1984) Shellfish toxicity and dormant cysts in toxic dinoflagellate blooms. In: Ragelis E (ed) Seafood toxins. American Chemical Society, Washington, DC, p $125-138$

Anderson DM, Chisholm SW, Watras CJ (1983) Importance of life cycle events in the population dynamics of Conyaulax tamarensis. Mar Biol 76:179-189

Anderson DM, Coats DW, Tyler MA (1985) Encystment of the dinoflagellate Gyrodinium uncatenum: temperature and nutrient effects. J Phycol 21:200-206

Anderson DM, Keafer BA (1987) An endogenous annual clock in the toxic marine dinoflagellate Gonyaulax tamarensis. Nature 325:616-617

Anderson DM, Kulis DM, Binder BJ (1984) Sexuality and cyst formation in the dinoflagellate Gonyaulax tamarensis: cyst yield in batch cultures. J Phycol 20:418-425

Anderson DM, Wall D (1978) Potential importance of benthic cysts of Gonyaulax tamarensis and $G$. excavata in initiating toxic dinoflagellate blooms. J Phycol 14:224-234

Binder BJ, Anderson DM (1986) Green light-mediated photomorphogenesis in a dinoflagellate resting cyst. Nature 322:659-661
Binder BJ, Anderson DM (1987) Physiological and environmental control of germination in Scrippsiella trochoidea (Dinophyceae) resting cysts. J Phycol 23:99-107

Binder BJ, Anderson DM (1.990) Biochemical composition and metabolic activity of Scrippsiella trochoidea (Dinophyceae) resting cysts. J Phycol 26:289-298

Chapman A.D. Pfiester LA (1995) The effects of temperature, irracliance, and nitrogen on the encystment and growth of the freshwater dinoflagellates Peridinum cinctum and $P$. willel in culture (Dinophyceae). J Phycol 31:355-359

Dale B (1983) Dinoflagellate resting cysts: 'benthic plankton' In: Fryxell GA (ed) Survival strategies of the algae. Cambridge University Press, Cambridge, p 69-136

De Statio BT Jr (1989) The seed bank of a freshwater crustacean: copepodology for the plant ecologist. Ecology 70 : $1377-1389$

De Statio BT Jr (1990) The role of dormancy and emergence patterns in the dynamics of a freshwater zooplankton community. Limnol Oceanogr 35:1079-1090

Gardner WD (1980a) Sediment trap dynamics and calibration: a laboratory evaluation. J Mar Res 38:17-39

Gardner WD (1980b) Field assessment of sediment traps. J Mar Res 38:41-52

Hori $T$ (ed) (1993) An illustrated atlas of the life history of algae, Vol 3. Unicellular and flagellated algae. Uchida Rokakuho, Tokyo (in Japanese)

Imai I (1990) Physiology, morphology, and ecology of cysts of Chattonella (Raphidophyceae), causative flagellates of noxious red tides in the Inland Sea of Japan. Bull Nansei Natl Fish Res Inst 23:63-166 (in Japanese with English abstract)

Imai I, Itoh K, Anraku M (1989) Dormancy and maturation in the cysts of Chattonella spp. (Raphidophyceae), red tide flagellates in the Inland Sea of Japan. In: Okaichı $T$. Anderson DM, Nemoto $\mathrm{T}$ (eds) Red tides: biology, environmental science, and toxicology. Elsevier, New York, p 289-292

Ishikawa A (1992) Population dynamics of the dominant dinoflagellates Scrippsiella spp. in Onagawa Bay, northeastern Honshu, Japan. M Agr Sci thesis, Tohoku Univ, Sendai (in Japanese with English abstract)

Ishikawa A (1995) Population dynamics of Scrippsiella spp. and other cyst-forming armored dinoflagellates with special reference to the role of cysts. PhD thesis, Tohoku Univ, Sendai

Ishikawa A, Fujita N, Taniguchi A (1995) A sampling device to measure in situ germination rates of dinoflagellate cysts in surface sediments. J Plankton Res 17:647-651

Ishikawa A, Taniguchi A (1993) Some cysts of the genus Scrippsiella (Dinophyceae) newly found in Japanese waters. Bull Plankton Soc Japan 40:1-7

Ishikawa A, Taniguchi A (1994) The role of cysts on population dynamics of Scrippsiella spp. (Dinophyceae) in Onagawa Bay, northeast Japan. Mar Biol 119:39-44

Lirdwitayaprasit T, Okaichı T, Montani S, Ochi T, Anderson DM (1990) Changes in cell chemical composition during the life cycle of Scrippsiella trochoidea (Dinophyceae). J Phycol 26:299-306

Matsuoka K, Fukuyo Y, Anderson DM (1989) Methods for modern dinoflagellate cyst studies. In: Okaichi $T_{\text {, }}$ Anderson DM, Nemoto $T$ (eds) Red tides: biology, environmental science, and toxicology. Elsevier, New York, p 461-479

Meksumpun S, Montani S, Okaichi T (1994) Changes in some chemical components of Alexandrium catenella and Scrippsiella trochoidea during their growth cycles. Fish Scl 60:207-212 
Nakahara H, Sako Y (1987) Tansui shokubutsu purankuton no seikatsushi (Life histories of freshwater phytoplankton). In: Kadota $\mathrm{H}$ (ed) Tansui akashiwo (Freshwater red tides). Koseisha Koseikaku, Tokyo, p 21-77 (in Japanese)

Pfiester LA (1977) Sexual reproduction of Peridinium gatunense (Dinophyceae). J Phycol 13:92-95

Pfiester LA, Anderson DM (1987) Dinoflagellate reproduction. In: Taylor FJR (ed) The blology of dinoflagellates. Blackwell, Oxford, p 611-648

Prakash A (1967) Growth and toxicity of a marine dinoflagellate, Gonyaulax tamarensis. J Fish Res Bd Can 24: $1589-1606$

Sako Y, Ishida Y, Nishijima T, Hata Y (1987) Sexual reproduction and cyst formation in the freshwater dinoflagellate Peridinium penardii. Nippon Suisan Gakk 53:473-478

Sasaki H. Nishizawa S (1981) Vertical flux profiles of particulate material in the sea off Sanriku. Mar Ecol Prog Ser 6 $191-201$

Steidinger KA (1975) Basic factors influencing red tides. In: LoCicero VR (ed) Proc 1st Int Conf Toxic Dinoflagellate Blooms. Massachusetts Science and Technology Foundation, Wakefield, p 153-162

Takeuchi T (1992) Shuyo akdshiwo shu no zoshoku dotalTanabe wan ni okeru arekisandoryumu no zoshoku dotai (Population dynamics of major red tide species - population dynamics of Alexandrium in Tanabe Bayl. Gekkan Kaiyo 24:17-24 (in Japanese)

This article was submitted to the editor
Uchida T (1994) Effects of temperature on the encystment and excystment of a dinoflagellate Scrippsiella trochoidea isolated from Muroran Harbor, Hokkaido. Bull Nansei Natl Fish Res Inst 27:243-249 (in Japanese with English abstract)

von Stosh HA (1973) Observations on vegetative reproduction and sexual Iife cycles of two freshwater dunoflagellates, Gymnodinum pseudopalustre Schiller and Woloszynskia apiculata sp. nov. Br Phycol J 8:105-134

Wall D (1971) Biological problems concerning fossilizable dinoflagellates. Geosci Man 3:1-15

Wall D (1975) Taxonomy and cysts of red-tide dinoflagellates. In: LoCicero VR (ed) Proc 1st Int Conf Toxic Dinoflagellate Blooms. Massachusetts Srienre and Technology Foundation. Wakefield, p 249-255

Wall D, Guillard RRL, Dale B, Swift E, Watabe N (1970) Calcitic resting cysts in Peridinium trochoideum (Stein) Lemmermann, an autotrophic manne dinoflagellate. Phycologia 9:151-156

Watanabe MM (1993) Scrippsiella trochoidea (Stein) Loeblich. In: Hori T (ed) An illustrated atlas of the life history of algae, Vol 3. Unicellular and flagellated algae. Uchida Rokakuho, Tokyo, p 60-61 (in Japanese)

Watanabe MM, Watanabe M, Fukuyo Y (1982) Encystment and excystment of red tide flagellates. I. Induction of encystment of Scrippsiella trochordea. Res Rep Natl Inst Environ Stud 30:27-42 (in Japanese with English abstract)

Manuscript first received: October 16, 1995

Revised version accepted: May 8, 1996 